\title{
Technology and Election Conundrum: A Case Study of Nigeria
}

\author{
Lai Olurode ${ }^{\mathrm{i}}$ \\ Department of Sociology, Faculty of Social Sciences, University of Lagos, Nigeria
}

Copyright $\bigcirc 2017$ by authors, all rights reserved. Authors agree that this article remains permanently open access under the terms of the Creative Commons Attribution License 4.0 International License

\begin{abstract}
Elections in Nigeria had often filled the air with apprehension and a high sense of trepidation. Stakes in elections are high. Under the zero-sum game which is in operation, winners take all and losers have nothing unlike the situation under proportional representation. In Nigeria, there are limited avenues by which individuals can benefit from states resources. By winning elections and getting recruited into the state sphere, an individual is assured of better life chances, so are close family members and ethno-religious constituencies. Elections are thus a matter of life and death. Electoral mal-practices are common. In 2011 but in the 2015 general elections in particular, there was a marked shift in the electoral process. Those who had been used to thwarting the electoral process were checkmated by the use of election technology, more specifically, the introduction of electronic card readers. The introduction of election technology paved the way for a more credible and competitive elections in Nigeria. All over Africa, election technology has become indispensable to conducting transparent elections that meet the standard of domestic and international observers. As for the method of research, the author relied on his experience as a member of Nigeria's primary electoral bureaucracy as well as his observations of election practices in other countries. Nigeria was used as a case study while references were made to other African countries as they struggle to diminish electoral impunity and frauds. This improvement in Nigeria's electoral process has triggered electoral reforms in other African countries.
\end{abstract}

(Comments by the then President-Elect, General Muhammadu Buhari, The Punch, May 7 2015).

'But we thank God for technology - PVC and card reader. If not for this luck we had with technology and the insistence of constituencies to make sure they were used, in two political zones where they were subverted, the people wanted to vote but they were not allowed to vote.

They continued with what they used to do - go to their party offices or their sitting rooms, write the results, go to radio house and television house and announce the result and say whoever does not want the result should go to court'
Keywords Election Conundrum, Electoral Mythology, Election Technology, Turn by Turn Nigeria

Election Conundrum: The crisis-ridden nature of electoral planning and execution. This can be disaggregated but not limited to the following:

(i) Recurrent security issues such as snatching of election materials, abduction, maiming and killing of election officials or contestants or their sympathizers and the commission of sundry criminal acts in the electoral process;

(ii) The fire brigade nature of electoral training and voter education;

(iii) The attendant logistic challenges of deploying election staff and materials over very difficult terrain;

(iv) Absence of cohesion within political parties, intra and interparty crisis, lack of discipline among political elites etc.; and

(v) The ordeals that citizens experience in merely exercising their franchise.

Electoral Mythology: Fetish beliefs, objects and incantations that are assumed as being capable of swaying electoral and political outcomes.

\section{Election Technology:}

[1] The adoption of information technology in generating a biometric voters' roll;

[2] The subsequent issuance of voter identity (referred to in Nigeria as the permanent voter card) without which a citizen cannot exercise voting right; and

[3] The use of smart card readers for ascertaining the authenticity of permanent voter cards. Though the card reader was expected to perform five functions on an election day, the most important is its ability to read PVC and detect fake ones.

Turn by turn Nigeria: The belief that political power should rotate among major ethnic groups in the six geo-political zones. This negates the principle of common citizenship. 


\section{Introduction}

Democratic indicators are now more evident and visible in Africa today than some three decades back. For example, as expressions of democratic indicators, elections now hold more regularly/periodically and term elongation is generally objectionable and regarded as an aberration, election days are known, election management bodies have legal backing, and there is press freedom. In theory, there is separation of power and the judiciary is allowed to function though not without constraints. Multiparty system features across countries and in elections in Ghana and Nigeria, opposition political parties had formed new governments. Africa's democratization has not only germinated but has begun to bear fruits. The fruits are in the number of countries now under one variety of democracy or the other. And more importantly, in the number of regimes that would readily act to defend democracy rather than dismantle democratic institutions. It would be recalled that some African leaders and their international friends collaborated to ease the exit of Laurent Gbagbo in Cote d'Ivoire and Yahyah Jammeh in the Gambia.

Though violent political outbursts and hate speeches do occur but these are no longer generally the norm. Voter education and commitment to making democracy work are visible and objections to them are loud. Open calls for military takeover of power are uncommon, and where they occur, they are roundly condemned. New political alliances across ethno-religious cleavages are being forged which are redefining identity politics. The role of technology in re-shaping Africa's electoral landscape has been profound. There is a strong theoretical argument that technology can be used to deepen Africa's electoral process, promote citizenship, enhance e-government and promote interface between State and Society.

Election technology has become indispensable to the electoral process in most of Africa as it featured prominently in generating the voters' roll by biometric means, the use of card readers in voters' accreditation and authentication and in a few cases, electronic voting has been accomplished, a sort of end to end solution. Heavy deployment and dependence on election technology had been witnessed in Cote d'Ivoire, the Gambia, Ghana, Kenya, Nigeria, and South Africa. Indeed, the idea of digital democracy is unfolding in Africa. Advocates of electoral reforms have consistently hinted on the need for a credible biometric register as a core infrastructure on which credible elections should rest [1]. The initial phobia for technology seems to be waning in the context of rising voters' awareness and the desire to checkmate fraudulent election practices and thereby enhance election security. It is not surprising that these days, unrelenting agitations for democratic and electoral reforms majorly centre on the precise role of technology in resolving some of the basic election logjam and conundrum that had bedevilled Africa's election administration for years. Both at the back end and front end of the electoral process, technology is increasingly being perceived as a necessity. But technology must not be perceived as a fix all phenomenon. Human agency has its own challenges which technology might not be able to address adequately.

To pose the question which this paper intends to address more pungently: has election technology made election outcomes to be more credible and less litigated today than in the pre-technology phase? Indeed, has election technology reduced instances of multiple voting or voting by proxy and indeed of the commission of electoral crimes such as snatching of election materials?

Though, there might still be some lingering concerns about the status of the voters' register in some countries in Africa but, definitely, those of them that deployed technology in the production of voters' roll have reduced the scale of complaints about the credibility of the voter roll by stakeholders. Biometric registers had been used in Kenya, Ghana, South Africa and Nigeria among many countries. Multiple registrations have been largely eliminated and voters' identity card made available. There are diverse routes that had been trodden by African countries in the production of credible voters' register and experiences differ. The point really, as Evrensel [2] has shown, is that voting procedure has undergone tremendous reforms through technological revolution in the past twenty years in most of Africa.

However, in the deployment of technology as a means of resolving election conundrum, African election managers must be circumspect so that purely technical failure is not interpreted as expressions of plans to perpetrate election fraud. Mozaffar and Schedler [3] have argued that 'the interplay between political suspicion and technical incapacity' may spark ardent disputes - preventing technical problems from contaminating an electoral process with corrosive suspicions is not an easy assignment. Of course, there are other challenges as to whether the deployment of technology on election days proceed as planned. If not, were there mitigating strategies or a plan B? A good election management body must anticipate challenges and thus be proactive so as not to trigger a conflagration in a country which may already be on the edge.

The major objective in this research paper is to examine the extent to which technology has aided improvement in Nigeria's electoral landscape as a case study, its implications for other African countries, outstanding challenges, and provide hints on the way forward. The methodology can be briefly enunciated.

\section{Methodology}

Much of the data in this research paper emanated from the author's experiences as a major participant observer and actor in Nigeria's electoral architecture and landscape between 2010 and 2015. He was one of the national commissioners that conducted the elections. From this vantage position, the author was involved in electoral policy 
formulation and implementation. Moreover, he served as a member of two strategic committees - Inter-Consultative Committee on Election Security (ICCES) and Information Communication and Technology (ICT). In meetings at the headquarters of the electoral commission (the Independent National Electoral Commission, (INEC)) and in engagements with stakeholders, the author made jottings part of which were relied upon in writing this paper. He also had unrestricted access to policy papers and research reports on Nigeria's elections during this period, all of which constituted materials in the writing of this paper. He relied on materials drawn from other key players with whom he partnered in and outside of the electoral bureaucracy.

\section{Political Economy Context of Nigeria's 2015 Elections}

Nigeria is an oil-dependent economy as it relies on oil rents for meeting its expenditure needs. However, Nigeria's control over its oil resources is weak as the sector is mainly dominated by foreigners who have the technical expertise as attempts to buoy up local content skill and capacity have remained a tall dream. However, rather than oil being the main driver of the economy, it is peasant agriculture that provides employment for the vast majority of Nigerians.

The oil sector remains volatile and susceptible to fluctuations in the global price of oil over which Nigeria exerts little or no control. Nigeria's economy is so vulnerable that any adverse change in the global price of oil immediately impacts on Nigeria's economy. The crash in the price of oil from over $\$ 100$ to about $\$ 50-60$ has provoked a drastic erosion of government revenue and a severe cut in expenditure. The National Bureau of Statistics, in its review of 2014 and outlook for 2015, outlined the implications of this shortfall in oil price for Nigeria. Though, an oil endowed country, Nigeria continues to import petroleum products which constitute a further drain on its dwindling foreign currency reserves. Nigeria's four refineries have been crippled by corruption and they remain epileptic. For reasons of decline in crude prices, the supply gap in the foreign exchange market increases the demand for dollars. In concrete terms, this decline in oil revenues means that governments at all levels have been unable to meet their obligations to the citizens - a plethora of abandoned projects, epileptic social services, several months of unpaid salaries, ${ }^{\text {ii }}$ rising debt profile, excruciating poverty, incessant violence, despondency, disillusionment, social discontent and rising crime levels. Paradoxically, public outcries and condemnations about the high cost of maintaining public office holders have remained unattended to. Itse Sagay [4], a Nigerian renowned public critic and scholar has lamented this situation as unacceptable. .ii

The political economy context in which Nigeria's 2015 elections were held was indeed a debilitating one, high level of youth unemployment and ravaging poverty of almost $70 \%$, generalised economic and social miseries coupled with an acute sense of insecurity particularly acts of terrorism, though now abating, in the north-east of Nigeria. However, the security situation in that part of the country was such that the election commission had to design a methodology for voting by the internally displaced persons (IDPs) in their camps [5a]. ${ }^{1}$ Apart from these concerns, there were heated controversies about which ethnic bloc should have the moral authority and not necessarily the legal right to contest the presidential election. Added to this was the emergence of a strong opposition party which came on board following a successful merger of four or so opposition parties. This could be referred to as the event of July 312013 . A review of the scanty literature on the subject matter is what follows.

\section{Literature Review and Theoretical Arguments}

The introduction of technology in any department of life often creates anxiety, fear of the unknown and even doubts as to its efficacy. The fear of change is real as old habits, indeed, old ways of doing things tend to persist even in the midst of profound change. In this context, new food menu takes time to become widespread. In the area of farming, new technologies are often resisted, sometime violently. Pilot projects are often advocated to precede any large scale introduction of new technologies. The electoral process is one sphere where a lot of caution and voter education are urged prior to the introduction of election technology. Even in the advanced countries such as Germany and the United States of America, doubts linger regarding the use of technology, especially e-voting in the electoral process. However, stakeholders are generally open minded and eager to consider reforms that can restore more confidence and trust in the electoral process, negate electoral malfeasance and guarantee one person, one vote. Though, election administration that is manually processed could be time consuming and more prone to electoral mal-practices but, election technology raises some theoretical puzzles. How for example do you make stakeholders in the electoral process who do not trust each other to readily subscribe to the notion of impeccability of technology? And we have in mind countries where technology in all its forms is low in usage and deployment. The answer may well be in the continued rupturing of social relations that had diminished communal affections and social solidarity, all of which fuel vested interest and primitive capital accumulation and greed for votes. With the introduction and familiarity with technology

1 The Commission set up a task force on internally displaced persons (IDPs) and the 2015 general elections. The task force collated information on IDPs and presented a report on January 122015 which guided the conduct of election in the three states of Borno, Yobe and Adamawa. Relevant security agencies were involved. 
in other departments of life (banking transactions, telephone conversations, health care, transportation, agriculture), citizens in Africa are probably coming to the conclusion that technology can equally be trusted in the electoral process. This theoretical line of argument is worth pursuing.

More than any other event, Florida's election conundrum in 2000 triggered debates on the appropriate place of technology in elections and it in fact led to the Help America Vote Act. In many states in the U.S., older voting technology was replaced with new ones as an aftermath of the Florida election fiasco[6][7] But technology is not enough, it must be coupled with training and election officials must be conversant with procedure, be respectful and ethical. What is even more important is that election technology must be accompanied with paper recording of every vote. This had been recognised by the US Congress and several states.

Nevertheless, Selker [8] called for extreme caution prior to passing legislation on end-to-end solution to election administration. The role of technology, not just in the electoral process but also in public administration is immense. Moynihan [7] in presenting the basic argument of the proponents of e-government as being that 'declining rates of trust in government can be reversed through the use of technology either indirectly through greater citizen satisfaction with more convenient services or directly through enhancing civic participation in the public sphere. When technology aids civic participation, this phenomenon is known as 'digital democracy', 'e-civics', and 'e-democracy' [6,7]. The prospects of failure of technology when massively deployed in the electoral process are real. The choices of vendor and technology are important. The goal of profit guides vendors' behaviour whereas the quest for trust, credibility and transparency are major concerns of election managers.

How to traverse these diverse, and sometimes conflicting interests are important issues for resolution. Without doubt, the culture of digital democracy is spreading in Africa and it is triggering profound changes in its democratization processes and State-Society nexus. The ways in which Africa's electoral landscape is being reshaped by election technology had been expatiated in a recent work, particularly its role in averting bloodshed in the electoral process [9].

Until recently, Africa had strong individuals, very powerful personalities and weak institutions. Ethno-religious identities were then more dominant in the political scenes. State power and resources were routinely appropriated by ethno-religious groups and cronies of leaders. One party states were then the rule rather than exceptions. These strong individuals were surrounded by sycophants and lobbyists most of whom were close family members, town folks and friends. With the wave of democratization that swept across Africa from the 1990s, institutions began to have a new life being breathed into them. Since then, political parties rather than strong men have been on the ascendancy. Agitations for political and electoral reforms have become louder.

The demand for greater participation and confidence in the electoral process has triggered series of strategies of assuaging reservations which encompass massive deployment of technology in the electoral process. This has enhanced the secrecy feature of balloting. Electorates have thus gained more autonomy from strongmen. Electoral fidelity has bright prospects, so is voters' confidence. In spite of occasional fiasco, votes are believed to count today than yesterday. Electoral bestiality and impunity are being overshadowed by best electoral practices. Vigilant civil society organisations, domestic and international observers are employing open and hidden agenda to enforce compliance with international best practice in the electoral process.

Thus technology is moderating while simultaneously leveraging individuality to enthrone a credible electoral process. With a clean register and thus voter roll for example, strongmen and electoral fraudsters cannot award scores arbitrarily and without judicial intervention. With smart card readers, those with fake voter cards can be denied access to the voting arena. Strong individuals are thus unable to write electoral history the way they wish. Thus when properly monitored and used, election technology combined with citizen's activism is capable of giving a voice to the people and thus get them connected to the state realm through transparent balloting.

The above theoretical insights may better robustly illuminate, explain and capture developments that culminated in Nigeria's unprecedented electoral change process. The personality that symbolizes the opposition was General Muhammadu Buhari. He was perceived across the country as ethical, incorruptible, disciplined, ascetic and one who is unlike most other leaders who were not only indolent but also indulge in opulence. Buhari had cut for himself a messianic and mythical image. He was charismatic, perseverant, has a large following and was regarded as a friend of the masses. In the context of Nigeria's sea of corruption, impunity and decay, Buhari was an island of a sort and an exceptional individual. Of course, it could be said that he had these personality traits in three previous elections but, he never made it.

What became plausible was that a presidential candidate's credentials may constitute a necessary prerequisite to ascend an epochal political ladder but, these may not be sufficient. There must be a vehicle that will convey these formidable credentials to the public domain and to which the personality can latch on to. This carrier was provided by an alliance of political forces particularly between the north and the centre of opposition politics in Nigeria, the south-west. This was what can be referred to as the revolution of July 2013. With Bisi Akande, an equally ascetic individual, a younger associate of Obafemi Awolowo and Bola Ige and a close ally of Bola Tinubu, an astute politician, and a respected opposition figure across the land, there could not have emerged a stronger oppositional politics than in the merger that produced APC.

Ethno-religious rivalry is deep rooted in Nigeria, and 
sometimes it defies logic. The belief is strong that no ethno-religious group should, ideally hold on to power for too long. This is euphemistically referred to as turn by turn Nigeria. Statistics in Nigeria point to the fact that about seventy per cent of Nigeria's population is in poverty. Social discontent was high, there was massive youth unemployment, high rate of crime, derelict social services delivery and poor quality of life in the midst of nauseating public display of opulence by the few people in power. There could never have been a better catalyst for change.

The role of election technology in moderating and midwifing this change cannot be glossed over, so was the general acceptability and believability of an electoral process that is driven by technology. The card reader technology conferred the process with elements of detachment. The scope for human agency and thus discretion had reduced with the introduction of election technology. Election technology not only depersonalises the electoral process, it mystifies it and patently portrays it as not only inevitable but also simultaneously immutable. Electoral outcomes could spring surprises as they are less certain with election technology. What follows in the next section is a highlight of Nigeria's 2015 general elections.

\section{Some Highlights of Nigeria's 2015 General Elections}

It is to the credit of Nigeria that since 1999, it has held 5 regular elections every four years - elections were held in 1999, 2003, 2007, 2011 and 2015. The elections of 1999, 2003 and 2007 were generally perceived as flawed by most stakeholders $[10,11,12,13]$. The voters' roll was not credible enough and there were sundry malpractices. Indeed, the International Crisis Group said about the 2007 elections: "The Elections, in the view of Nigerians and the many international observers alike, were the most poorly organized and massively rigged."

With this background, the new electoral commission under the leadership of Professor Attahiru Jega, upon being inaugurated (in June 2010), took certain decisions that could be said to have turned around the image of the Commission and the confidence that stakeholders began to repose in it. The electoral commission also struggled to maintain a respectable aloofness from the political class. It engaged the key stakeholders in major decisions in the electoral process. The Commission's activities were more open and transparent. As much as possible, the Commission was focused and displayed a measure of cohesion and espirit de corps and consistently struggled to rise above internal bickering.

Preparatory to the elections, a new biometric register of voter had been complied which was rid of strange and foreign names as were in the previous register. The new register contained names, photographs, addresses, finger prints and other details of all eligible voters. Thus upon the conclusion of the 2011 elections, the country heaved a sigh of relief. Key stakeholders including domestic and international observer groups lauded the electoral process and the outcome as credible enough and much better than the previous ones of 1999, 2003 and 2007. ${ }^{\text {iv }}$ Stakeholders in the electoral process started to clamour for further reforms of the electoral process. Their argument was that having compiled a biometric register, further steps needed to be taken to rid it of double registrants as well as replace the temporary voter cards which were used in 2011 with electronic ones that could be verified by card technology.

The Commission thus took the decision to replace the temporary voter card (TVC) with permanent ones - the permanent vote card (PVC). The voter register was thereby further sanitized and a total of over four million duplicates were removed when the automatic finger identification scanner (AFIS) was run. From a figure of over 73 million registrants collected during the 2011 registration, by 2015 after subjecting the register to cleaning and other scientific screening, the figure came to over 68.8 million, 82 per cent (or 54,460,968) of whom were issued with PVC for participation in the 2015 elections.

Having being persuaded by the electoral commission, government decided to fund the card reader project and following series of meetings, our election methodology was agreed to by the core stakeholders who shared the view that it would further confer credibility on the electoral process. Our election methodology approved of a card reader for each of about 158,000 polling stations with about five back up for each of the over 8,000 wards. Technical personnel were trained and deployed to the field accordingly just in case of equipment failure. Some challenges were encountered in the course of continuous voter registration which predated the elections but, these were satisfactorily resolved to a large extent.

Generally, the elections proceeded as planned and were peaceful. In spite of a few logistics logjam, most polling units opened on schedule. Party agents were generally present, so were domestic and international observers. Sorting and counting were undertaken as expected. Scores were posted at polling units as instructed and poll officials suffered no major intimidation. The voters' turnout in the presidential election was $43.65 \%$ and rejected votes constituted $2.86 \%$. Voter turnout in 2011 was $43.7 \%$ while wasted votes constituted $3.2 \%$.

The election environment was carnival-like. Voters' enthusiasm was overwhelming. Community assets in the electoral process were profound, though usually unofficially recognised in computing cost of doing elections. Election observers, within [14] and without [15] expressed satisfaction with the process. ${ }^{v}$

\section{Persistent Election Conundrum}

Contests for elective positions in Nigeria are not only expensive, but also protracted, energy sapping, cantankerous 
and could be life risking as well. A political office seeker could lose all or gain all. In this regard, what counts most is the end rather than the means of getting there. It is generally known that by whatever means you get there, fortune could smile at you for close to four years before the legal nemesis may catch up with you. The pay and perquisites of office are just too attractive to be ignored. The mind-set is one that believes in winning elections at all cost. Nigeria's electoral landscape is filled with diverse and unbelievable acts of impunity by political players. Political parties breach their own constitutions and rules with impunity. Internal party democracy is rarely allowed and imposition of candidates by god fathers is a common phenomenon. Acts of hooliganism, abduction and even killings of opponents are common. Snatching of election materials are common and illegal thumb printing of ballot papers is rampant. Some political rascals could decide to snatch result sheets and write their scores and get them announced. Connivance with election staff is a common place. Indeed, a typical election day is real fiasco as it is chaotic and may be disordered. Moreover, election management bodies are rarely trusted and even with reforms that had been advocated and partly implemented courtesy of the Justice Uwais [16] electoral reforms recommendations, the question of trust of election management bodies has not abated. A consistent allegation is that INEC is colluding with one of the political parties to rig out other contestants.

Acts of impunity that are common features among members of the political class are being reinforced by dimensions of electoral mythologies [9] such as the placement of empty coffins in strategic places in the city and the use of curses as a means of inducing people to cast their votes in a particular way, the use of incantations and hate speeches. There are those who believe that thumb printing can mysteriously disappear after voting because ballot are made of photo-chronic paper. Voters are urged to recite portion of the Qur'an or the Bible as may be relevant to protect their votes and thus seal their choice. Vote buying is common. There is now an electoral lexicon which has been made popular by one of the state governors in Nigeria, this is the concept of stomach infrastructure which means that voters are not just going to vote for you because you have provided physical infrastructure, what happens to their stomach. vi As an election management body, the Commission put in place some measures that should help reduce the scale of election conundrum in the polity - we got the parties to form inter-party advisory committee (IPAC), we met them on quarterly basis and got them to agree to a code of conduct. It is yet to be discerned if the mind set of political elites are being altered in favour of more peaceful conduct during electioneering and during elections proper.

Competitive elections under the above scenario of election conundrum or elections that would correctly gauge and reflect people's preferences are problematic, only a landslide victory is feasible. Election outcomes are predetermined or programmed, no scepticism of a sort. And Nigeria in 1983 had a landslide victory that was unsung. It is partly in response to these electoral malfeasances that critical stakeholders in matters of electoral democracy have been agitating for an increase in the tempo of technology in election administration. Civil society organizations, media practitioners and judicial activists have been at the centre of the clamour for change in election administration. Election observer groups, both domestic and international observer missions have also been supportive of electoral reforms. Nigeria's election management body struggle hard to negotiate very difficult election terrain and meet up with standards that had been set by regional and global election observer teams. Though, the intervention of election technology has restored electoral fidelity in some aspects of election administration in Nigeria, in my mind however, the emergence of a strong opposition in 2013 was partly responsible for the competitiveness and integrity of the 2015 elections and a major counterforce in stampeding the human agents behind election conundrum. Some information on how the disparate opposition groups merged may be apt. ${ }^{\text {vii }}$ It is perhaps premature to know if the opposition is for real.

With the merger and the card reader as a game changer, it became obvious that the 2015 general elections would be the most competitive in Nigeria's history. Political tendencies in Nigeria are not water tight or neatly packaged. The borders between political parties are indeed porous, and movement in and out of them create no dilemma for those involved in the oscillation. In order to underscore how similar they were, a Nigerian politician once referred to the then political parties as five fingers of a leprous hand. Nigeria's twoviii major political parties could be regarded as being on the same continuum, one more to the right of the political spectrum (the Peoples' Democratic Party - PDP) and the other more to the left of the centre (the All Progressive Congress - APC). The PDP could be regarded as an establishment party, status quo oriented, a sort of laissez-faire with strong commitment to a market oriented economy and private capital protection whereas the APC could be regarded as a welfarist party with an active role for the state in subsidizing health and education services, a sort of abundant life for all as encapsulated in the ideology of the defunct Action Group of Nigeria, and the Northern Elements Progressive Union (NEPU) in the first republic. In its manifesto, APC outlined its cardinal programmes to the Nigerian public as follows: war against corruption, food security, accelerated power supply, integrated transport network, free education, devolution of power, accelerated economic growth and affordable health care. In the next one or two years, we will begin to see if indeed there are differences between the major political parties with regard to meeting people's existential needs.

The narratives in section 6 above on Nigeria's political class must really be depressing as it portrays a class that sees winning elections as a certainty rather than a possibility. In the next section, we will examine the extent to which interventions by election technology have assisted in 
mitigating and curbing some of these election conundrums.

\section{Interventions by Election Technology}

In the world in which we live today, the role of technology is pervasive and it in fact dominates our lives, social networks, the choices we make, our movements, our work, our health and even the way we think. Technology has indeed made life and living easier and predictable across the globe. We live in a technology dependent world and every department of life is affected by it. Even the barely literates use technology in banking transactions and the use of mobile phone in communication is widespread. There is therefore no justification not to admit of its relevance in election administration as it has the potential to reduce not just the cumbersome nature of election administration in some countries but, it can also confer more credibility and believability on the electoral process as technology can help to filter the process of impurities in the electoral process. It must be mentioned that election technology on its own cannot right all wrongs in the electoral process. The need for human agency and vigilance are not to be discarded merely because of the introduction of election technology. Its introduction presumes that adequate voter awareness and education had been undertaken to ensure stakeholders buy-in and endorsement so as to remove fears and clear doubts. A wholesale application is ill advised. Prior testing is key to success especially in a small scale election. The market of election technology is wide and diverse. The objectives of the vendor and those of the consumer are not necessarily in tandem. A number of doubts must be cleared before a final decision is made to purchase a solution to the resolution of election conundrums. Some specific areas in which technological solutions had been sought will now be mentioned.

Most African countries now have electronically generated biometric voters' roll. There are however, some credibility questions with most of these registers with regard to completely removing duplicates and names of deceased people or transferring people that had re-located to their new locations. We were not able to do this in Nigeria during the 2015 elections. Updating the register through continuous voter registration was not also fully accomplished or neatly executed. In a few instances, there were people whose names were missing on the register. We have also been able to produce permanent voter card (PVC) with embedded chips of close to seventy million and succeeded in distributing over eighty per cent of this figure to their owners ${ }^{\text {ix }}$ Temporary voter cards (TVC) which were used for the 2011 elections were replaced with permanent voter card (PVC).

The electronic register and the production of PVC were helpful in sanitizing the electoral process. This was in spite of stakeholders' reservations with challenges which trailed the issuance and collection of PVC and instances of missing names on the register. Well over four million people were removed from the register. The biometric register and PVC had helped in resolving a major election conundrum around the register and eligibility to vote. The use of the smart card reader as a technological election solution was generally perceived by the stakeholders as supportive of election integrity. But was this the actual experience and what were the challenges and how were these mitigated?

The decision of the commission to use the card reader, though a master stroke, provoked diverse reactions from stakeholders. There could be said to be broadly two schools of thought. The first was opposed to its use as it had not been previously used in any previous small scale election in the country and there was no guarantee that it would work, be risky to experiment with the 2015 elections as the consequences of failure could be unmitigated disaster. Questions were also raised about the possibility of pre loading the card reader before election and there were fears that people could be disenfranchised where the card readers failed. Issues were raised with the battery life, ruggedness of the machine and possible theft and back up. Most members of the ruling party opposed the use of card readers on grounds that had been enunciated and saw in them a future project for 2019. A second school of thought saw in the card reader a magic wand that is urgently needed to checkmate election fraud and particularly multiple voting in the country and thus a resolution of a major election conundrum in the country.

In a widely publicised meeting with the National Council of State, Nigeria's highest advisory forum for government, INEC was asked to make a presentation on the state of its readiness for the elections. Upon listening to the Chairman of the Commission, the body advised the Commission to consult widely with other stakeholders before arriving at a final decision as to whether elections can go as scheduled. $x$ The presentation shows that first, a large number of PVC were yet to be distributed, second, many were also yet to be printed and third no extensive field testing of the SCR had been undertaken. The commission had previously met with the National Security Adviser and the service chiefs who had opined that elections may not proceed as planned because of recent support that government had received from neighbouring countries on military campaigns in the north-east. ${ }^{x i}$ After series of consultations [5b] with stakeholders - political parties, civil society organizations and others, the commission took the advice to postpone the elections by six weeks to March 28 and April 11 [5c]. ${ }^{\text {xii }}$ This decision drew a lot of flak from the opposition and government alike. In the view of the opposition, INEC was being used to truncate the democratic process and in government circle, INEC was castigated for lying to the country on its state of preparedness. It was obvious from our engagement with the security chiefs that security challenges, though real, were a mere smokescreen.

The Commission went back to the drawing board and utilized the window provided by the six week postponement to undertake a rigorous field testing of the card reader as well 
as print and distribute more PVC [5d]. As at the time of the election, PVC distribution went up from just about 65 per cent to over 80 per cent distribution which was a remarkable improvement. ${ }^{\text {xiii }}$

In order to underscore the critical role of the card reader in the 2015 election methodology, the accreditation and voting procedure (which is unique and regarded as cumbersome by some) should be noted. Theoretically, polling stations open at 8 a.m. for the first leg of the exercise which is accreditation. A prospective voter is expected to show up with his PVC and upon the presentation of this, the presiding officer looks up the name in the register, if the name is contained in the register, the prospective voter moves on to the assistant presiding officer who uses SCR to read the PVC. If the machine fails to read the card reader, the person is turned back and the assumption is that the PVC is fake. But if the PVC is read, the would-be voter moves on to have his/her fingers authenticated by the SCR. If after three or so attempts, none of the fingers could be authenticated, this is noted in the incident form but, the voter is not disenfranchised by this failure. This process of accreditation comes to a close at $12.30 \mathrm{p} . \mathrm{m}$. and voting proper begins at $1 \mathrm{p} . \mathrm{m}$. when all those previously accredited are expected to return to the polling station for voting. ${ }^{\text {xiv }}$ Only accreditation is electronic but voting (casting of ballot) remains manual. INEC, from what is read in the papers, has now collapsed accreditation, authentication and voting-all now take place simultaneously. The next section will discuss key findings on the adoption of election technology.

\section{Key Findings on the Adoption of Election Technology}

The adoption of election technology will be examined in three areas - biometric register of voters, the issuance of permanent voter card and the adoption of the smart card reader in the accreditation of voters. Undoubtedly, the decision of Nigeria's election commission to deploy election technology from the 2011 elections and an enhanced version of it in the 2015 elections has added tremendous value to its electoral outlook.

The deployment of the card reader was a particularly useful technological device in navigating Nigeria's turbulent electoral landscape. It has been helpful in reducing the number of ghost voters and those who indulge in multiple voting. Probably, many with cloned cards or fake PVC did not have the courage to show up on the Election Day. The news had gone round upon the conclusion of the field testing of the card reader that only PVC that were issued by INEC were read. The use of PVC to do accreditation also cut down the number of people voting. With the elimination of double registrants and the use of the PVC, the register became more real and manageable than in previous elections. Evidence of prior accreditation moderated the number of people that could vote. The fact of a voter's name being on the register is a necessary but not a sufficient condition for voting. In 2011 when we used the temporary voter card for the general elections, the number that voted in the presidential election was $39,469,484$ whereas in 2015 election, the corresponding number was $29,432,083$, a difference of more than ten million $(10,035,401)$ - the figure went down by more than 25 per cent. How could over ten million voters have disappeared between 2011 and 2015? The card reader had evidently helped to screen off fake voters and thus a resolution of a major election conundrum. This is the first point.

A related point is the margin of defeat between the two leading candidates in 2011 and 2015. In the 2011 elections, Jonathan defeated Buhari by about 10 million votes whereas in 2015 Buhari defeated Jonathan by just 2,571,759. Thus with the use of the card reader technology in 2015, the presidential election was more competitive as the margin of defeat narrowed. Whereas in 2011, Jonathan scored at least $25 \%$ in 31 states, Buhari did so in only 16 states. By 2015 , while Buhari's APC scored at least $25 \%$ in 27 states, Jonathan's PDP did so in 26 states (from the 31 states where he did so in 2011).

With regard to the distribution of seats in the national assembly, the ruling party (the People's Democratic Party) had an overwhelming majority of both the senate and the house of representatives - it had over $60 \%$ majority in the senate and over $56 \%$ in the house of representatives in 2011 but in 2015 it had the following figures respectively $-44 \%$ and $36 \%$. On the other hand, the opposition had 55\% majority in the senate and $58 \%$ majority in the house. The table had been turned against the ruling party - the dominant political party had become the minority. With this party composition at the national assembly, there will be need for inter-party cooperation and understanding to conduct legislative business and a lot of political brinkmanship and skill would be required. Out of the 36 governors, the opposition APC had 22 carrying its flag whereas PDP had 13 and APGA 1. The PDP had also lost out at the Governors' Forum as well. From the result of the national assembly elections and governorship elections, election technology had fostered competitiveness in place of landslide victories.

At a second level, it will be interesting to find out if election technology had assisted in minimising the intensity of political contestation, acrimony and cleavages? On the surface, this could not be said to be so, especially if we recall several incidents of killings prior to and after the elections, snatching of election materials and several other acts of desperation ${ }^{x v}$ including hate speeches. One indirect evidence that could be used as a proof that election technology had reduced the intensity of political struggle is the number of losers who are willing to go to court in 2015 compared to 2011. By way of comparison, in 2003, 560 election petitions were filed before election tribunals, in $2007,1,250$ cases were filed and 400 in 2011. In the post 2015 elections, 650 cases were filed [16]. In fact, for the first time since 1999, no presidential election petition was filed. Election technology has been supportive of election 
credibility, competitiveness, integrity and transparency.

Most of the election petitions were on the card readers. Unfortunately, the judicial attitude to the adoption of technology in the last general elections was negative [17]. There were widespread allegations that election petition judges had been compromised and that they had poor knowledge of card reader technology.

Thirdly, what could we say about the expenditure of time, can it be said that an average voter now spends less time doing accreditation and voting? There is paucity of data to respond to this poser satisfactorily. What one can say is that there are different strokes, in some polling units where presiding officers that had been trained were deployed, reports indicated that their mastery and dexterity were marvellous whereas in other instances tardiness and poor skill display were common. Now that accreditation and voting now take place simultaneously, time expenditure on election by voters is on the decline.

\section{Election Day Challenges and Mitigation Strategies}

A typical election day in Nigeria could be said to be prolonged and cumbersome. In term of time expenditure, it is a whole day - from 8 a.m. to 6 p.m. or even to the second day in some cases. Voters may sometimes become impatient at the long drawn procedure of first accreditation and then voting. With poor training and illegal substitution of trained ad hoc election personnel, would-be voters generally could become frustrated at the slow pace of the exercise. The Commission was forced by circumstances to announce a modification of the voting methodology, that card reader could be by-passed in favour of manual accreditation. It would be recalled that the machine failed to read the PVC of President Goodluck Jonathan and his wife after several trials in Bayelsa State, the president's home state. By mid-day on the date of the first elections, reports from the field indicated general failure of the card readers. The Commission met quickly and issued a statement which authorised manual accreditation $[5 \mathrm{e}]^{\mathrm{xvi}}$

Though, the Commission anticipated that this could happen but the attitude of the Commission and the popular saying of its chairman was that "when we get to the bridge, we will cross it". Moreover, there was the fear that if this mitigation strategy was disclosed earlier, many ad hoc staff will simply ignore the use of the card reader in favour of manual accreditation. There was the possibility that many fake PVC could have found their ways to the voting arena. By the date of the second election on April 11, the Commission made efforts to rectify identified lapses and technical hitches in the card readers and insisted that card readers only will be used, no manual accreditation. The fact that voting spilled over to the second day following poor mastery of the card reader combined with difficulties in finger prints authentication probably mean that voters spent more hours exercising their franchise than before the introduction of election technology.

Though it could be purely accidental, the fact remains however that the adoption of election technology produced the first ever competitive election in the history of Nigeria and indeed an election in which a sitting government lost. Of course, it would be illogical to assume that merely deploying election technology into an electoral process would on its own produce a competitive outcome but doing so in the context of other socio-economic and political forces, all operating simultaneously can provoke such an outcome. It therefore means that when election technology is mobilised to sanitize the election environment and rid it of common conundrums, the opposition stands a better chance of receiving electoral justice. This point about the role of technology in whether an election would be won or lost has also been mentioned by some key players on the side of government though in a different context. ${ }^{\text {xvii }}$ From Nigeria's experience, African countries should be cautious about wholesale deployment of technology without extensive testing for reliability and ruggedness. In an ethnic divided society, it is easy for technological puzzles to feed on pre-existing fault lines, thereby provoking anxiety and generalized chaos. In the next section, some data will be presented on election outcomes to demonstrate their competitiveness.

\section{Can We Make Sense of the Election Outcomes?}

Competitive elections are a rare occurrence in Nigeria even under multi-party electoral politics. Land slide victory for a pro-military political party in the era of military transition to democracy or for the government in power under the current dispensation was a common phenomenon. It was also a weakness of the era that while there is a strong political party which wields enormous power, there would be a motley of opposition parties that had historically failed to present a united front to confront the political party in power. All previous attempts by opposition political parties to present a formidable opposition had not materialized until now. The coming together of the main opposition parties was a factor in the competitiveness of the elections. Of course, credit must be given to the government of President Goodluck Jonathan for its providing an enabling environment for the opposition to triumph. The body language of the administration was such that was accommodative and tolerant of dissent. Jonathan was known to have said that his re-election bid was not worth the blood of any Nigerian.

Secondly, there was a general perception that the government in power at the centre was unable or could not address security challenges, especially the war on terror in the north-east of the country. The scale of human suffering arising from these diverse acts of terror had become 
unbearable. To make matters worse, there was the daylight abduction in 2014 of over 200 Chibok schoolgirls that were yet to be found. Apart from security issues, power supply challenges had become acute in spite of high spending and promises that the situation would normalize. And this is the third point or factor that accounted for the competitiveness of the election. It would appear as if the level of social discontent was unprecedented. That most Nigerians were desirous of political change in a new direction was apparent and clearly expressed in their resilience to exercise their franchise in spite of avoidable impediments. So much enthusiasm was displayed in the collection of PVC and even in the continuous voter registration exercise.

Community assets in these exercises were impressive. Civil society organizations, to a greater extent, in their advocacy and voter education activities, assisted in galvanizing and mobilizing the general populace in the direction of change. These constitute the fourth point in the competitiveness of electoral politics. The fifth factor is the international community which actively promoted the prospects of power transfer to an opposition political party in Africa's largest democracy. At a point in the election process and particularly during the presidential collation, the US Ambassador to Nigeria could not hide his enthusiasm and was sighted around the collation centre. He also poured encomium on the election management body and applauded its use of PVC and even rated it as better than what obtained in his home state in the US. ${ }^{\text {xiii }}$ Nothing could be more patronizing. ${ }^{\mathrm{xix}}$

Internal crisis within the government party did also not help matters. Internal party democracy was lacking, imposition of candidates was a common phenomenon and defections of even elected members to the opposition party became frequent. These defections were aided by sentiments among major political players in government and within the opposition party that it was the turn of the north to produce the next president. This is referred to as turn by turn Nigeria. The crisis within the ruling party had several dimensions there was the failed attempt by the Governors' Forum to produce its chairman which failure was actively engineered by government, there was the visible assault on the status of major power brokers including former president Olusegun Obasanjo who was reduced to a point of insignificance and irrelevance in party affairs in his home state. So bitter was he that he had to tear his part membership card publicly. ${ }^{\mathrm{xx}}$

A more significant way in which we can make sense of the election outcome is in the sense in which technology created the way for the first ever competitive elections in Nigeria's history. Secondly, there could have occurred massive disenfranchisement of a vast majority of the electorates in North-East Nigeria where people had become internally displaced. With the aid of technology, the electoral body was able to afford them an opportunity to vote. Thirdly, electoral disputes become easier to resolve in courts with the use of card readers which are capable of furnishing incontrovertible evidence of over-voting among other electoral malfeasance.
This was not possible in the pre election technology era.

\section{Lessons Learnt and Anticipating 2019 General Elections}

In understanding the limited success story of the previous commission, (2010-2015), the readiness to learn from other election managers is a critical factor among others. Elections should be regarded as a science which then makes learning from the accumulated experiences of others a routine rather than seeking to re-invent the wheel. Thus the Commission never played down on the role of research, training and open engagements with informed people before it took decisions. The Commission was tolerant of divergent perspectives to issues and deferred to superior logic as it took key decisions. The leadership style of the Chairman of the Commission, Prof. Attahiru Jega is commendable in this respect. Except on one or two occasions when external political cleavages intruded into the Commission's decision making process, generally, the Commission often acted without pronounced disagreement. Occasional differences cannot be ruled out given the ethno-religious diversity of members, ideological leanings and class orientations. Secondly, as an art, the Commission realised that election administration requires having a scope for discretion and creativity as situations never contemplated in its planning may crop up for resolution. Thirdly, where the Commission erred, it come clean and admit, and if necessary apologised. This sincerity earned it trust and respect among stakeholders. Fourthly, in pooling ideas, the Commission gave an opportunity to low and medium cadre staff to have an in-put. We do not allow the hierarchical arrangement of the Commission to inhibit flow of ideas. This gives room for participation across the board. And this gives a sense of belonging and ownership to even junior staff.

However, as an election commission, INEC had some structural and institutional challenges. A major challenge is Nigeria's federal structure which is so only in theory and not in practice. The hierarchical structure of Nigeria tends to exert negative impact on government agencies and parastatals including INEC. The centre of organizations holds too much power whereas election administration requires a more flexible arrangement that affords discretion at the lower level to respond to challenges without having to wait for decisions from the centre. Nigeria is diverse and responses to electoral hiccups need not be uniform or centralised once they are within broad policy direction. Procurement is often centralized. For example, the Commission could have done better with decentralization of the printing of PVC at zonal levels than was the case.

The relationships between the Commission and its state offices and between the latter and local governments need more specificity. There were also numerous institutional constraints some of which relate to the size of the organization, discipline and ethical issues. There seems to be 
space for volunteers in election management in Nigeria which is not being tapped. It will certainly reduce election cost to the Commission. In the 2011 elections, INEC budgeted millions for tables, chairs and canopies, most of which are often available in schools and communities. It also avoided this waste in the 2015 elections. There are ample electoral assets in the community that electoral bodies can mobilise. The National Union of Road Transport Workers was happy to partner with the Commission in the 2015 elections. The Commission in the 2015 reached a memorandum of understanding with it, and the partnership worked for Nigeria.

From the Nigerian experience, election project must not be too elaborate and must not seek to introduce many innovations within a short period. Once decisions have been taken by an electoral commission to bring on board new election technology, engagements with stakeholders must be robust, so is voter education which should be vigorous and culture centred. No effort must be spared to win over the government in power to secure its buy-in of the innovations, not just funding but attitudinal change and matters of trust. Second, procurement must be prompt and time lines as set out in the election project plan must be respected. Third, those whose services are to be engaged, say, in the printing of PVC must have vast experiences in the business and a number of contractors must be engaged, a monopoly situation must be avoided. Fourth, once the cards are printed, they must not be allowed to pile up. Distribution must commence immediately. Intense voter education and culture-friendly procedure must be adopted in the distribution.

Fifth, a pilot of election technology in an election-like situation is key to success and if surprises are to be avoided. INEC made a costly mistake of not trying out the card reader in a small scale election before the large scale deployment for the general elections. Sixth, Nigerians could not vote with their PVC from any polling unit in the country. This resulted in a large number of people not being able to exercise their franchise even though they have PVC. Hopefully, this should be corrected before the next elections. Seventh, Nigerians in the diaspora could not participate in the exercise, so were security agents, election ad hoc staff as well as INEC permanent staff, prisoners and those who were sick in hospitals or in their homes. In a close election, this number could matter. Eighth, the continuous voter registration was problematic. There were a number of would-be registrants whose data could not be captured. The Commission needs to craft a more robust plan for truly making the exercise continuous. Also, finger prints authentication can be dispensed with and this at no risk of undermining the credibility of the system. Lastly, the shift in election dates appeared to have, unfortunately though, been forced on the Commission. With the benefit of hindsight, the Commission ought to have pre-empted government and prevented an obvious erosion of its power to fix election days.

INEC ought to have been pro-active, the more so when it was clear that some extra weeks would afford it an opportunity to distribute more PVC and test run the card readers more vigorously. But the Commission was restrained from openly admitting it needed more time to avoid playing into the hands of those who wanted to exploit postponement to avoid election and thereby forcing tenure elongation on Nigeria, ostensibly because INEC was not ready - a smokescreen of a sort.

\section{Conclusions}

Without doubt, Nigeria has made progress on its political and electoral landscape - it had held five elections at the pace of every four years since 1999. Considering its land size and population, holding five consecutive elections throw up huge logistic, cost and administrative challenges in the context of weak infrastructure. And all those elections could not be labelled as flawed, at least not the transition elections of 1999 nor those of 2011 and 2015. In fact, one of these elections threw up an opposition political party winning and forming a new government. This was unprecedented in the history of elections in our country. What had produced this impressive outcome is the determination of Nigerians that no matter the odd, the democratization train must not be allowed to go under. That Nigerians had demonstrated an unbelievable level of enthusiasm and tolerance of electoral ordeals is not in doubt. These to me are some of the features of the social capital that continue to water our democratization process.

From the data presented above, it is evident that the introduction of technology has tremendously improved the electoral process in Nigeria and other parts of Africa. Electoral frauds have become easier to prove and detect than hitherto was the case. Multiple voting or voting by proxy are now rare as permanent voter cards can only be read once and carry photo identity. Ghost names are being regularly eliminated from the voter roll. However, continuous improvement in training of staff including temporary election staff is key to sustaining the success so far attained. In this connection, a data base for members of the National Youth Service Corps is urgently needed so that they can continue to be recycled into the electoral process instead of being trained, used once or twice and then discarded. Investments in them should be tapped for as long as they are available and willing. Constitutional, legal, electoral and political reforms must be a continuous engagement. These reforms must seek to reconcile conflicting sections of the 1999 constitution as amended and those of the electoral act especially on how aspirants and candidates emerge in primary elections. Attention must also be paid to the remuneration of elected and public office holders in order to bring it at par with the pay of an average Nigerian. A major impediment to strengthening political party system in Nigeria is the stark absence of internal party democracy and the usurpation of the power of all by an oligarchy within the political parties. This means lack of participation by the 
majority in the affairs of political parties and thus alienation. Election management bodies must be selective in their choice and adoption of new ideas coming from development partners. Attention must be paid to culture, cost and autonomy. Pilot trials of new technologies are recommended, so is overhauling and replacement of old ones.

Leading sectors of the economy must be made to contribute to the cost of conducting elections through support for voter education. The involvement of the private sector must be with caution so as to avoid abuses. Violence has persisted in our electoral process for long and this seems intractable. Statistics of electoral offenders continue to be befuddling and yet prosecution is at a snail speed. It is important to consider the setting up of election offenders' commission before the next general elections in 2019. All these reforms should prevent a possible reversal of the political gains of the past years as we move to the phase of consolidation. Continuous training in election technology and replacement of obsolete ones are important to keep pace with development in the field. The point must be made however, that technology cannot fix all challenges associated with elections.

\section{REFERENCES}

[1] 'Lai Olurode and M. Ahmad Wali "Citizenship and Electoral Reforms in Africa"” Friedrich Ebert Stiftung, Discussion paper No 6 www.fes-nigeria.org 2014

[2] Astrid Evrensel (ed.) Voter Registration in Africa: A Comparative Analysis. Electoral Institute for Sustainability of Democracy in Africa (EISA). 2006

[3] S. Mozaffar and A. Schedler, 'The Comparative Study of Electoral Governance' International Political Science Review Vol. 23; No1. 5-27. 2002

[4] Itse Sagay, Political Maturity Ethics and Integrity: The Missing factors in Nigeria's Public Life. Lagos: Rebonik Publications. 2012

[5] Independent National Electoral Commission (INEC); a. Document on IDPs voting. January 2015; b. Decision Extract of February 12 2015; c. Decision Extract on Utilization of the Six Weeks Extension. d. Chart on Distribution of PVC; e. Press Statement March 28, 2015
[6] Laurie Robertson, 'One Man One Vote: Trust between the Electorate, the Establishment, and Voting Technology' The Journal of Technology Studies, Vol. 32, No. 1/2 (Winter/Spring 2006), pp. 85-89. 2006.

[7] Donald P. Moynihan, 'Building Secure Elections: E-Voting, Security, and Systems Theory' Public Administration Review, Vol. 64, No. 5 (Sep. - Oct., 2004), 515-528. 2004

[8] Ted Selker, 'Election Auditing Is an End-to-End Procedure' Science, New Series, Vol. 308, No. 5730 (Jun. 24, 2005), 1873-1874. 2005

[9] 'Lai Olurode, 'The Slaughter's Slab as a Metaphor ... ', Inaugural Lecture delivered at the University of Lagos. March 2017

[10] 'Lai Olurode, and Remi Anifowose, Issues in Nigeria's 1999 General Elections. Lagos: John West and Rebonik Publications. 2004

[11] Solomon O. Akinboye, "Nigeria's 2007 General Elections: Global Perceptions, Concerns and Responses" in The Crisis of Political Succession edited by Lai Olurode, Solomon Akinboye and Rasheed Akinyemi. Lagos: Rebonik. 192-213. 2009.

[12] Rasheed Akinyemi, "Election Monitors, Local and International Observers" in The Crisis of Political Succession edited by Lai Olurode, Solomon Akinboye and Rasheed Akinyemi. Lagos: Rebonik. 214-241. 2009.

[13] Waziri Babatunde Adisa and Ayobade Adebowale, "The Nigerian State and Patterns of Electoral Corruption in the 2007 General Elections" in The Crisis of Political Succession edited by Lai Olurode, Solomon Akinboye and Rasheed Akinyemi. Lagos: Rebonik. 242-265. 2009.

[14] TMG, The Report of The Transition Monitoring Group on the 2015 Elections. 2015

[15] European Union Election Observation Mission 'First Preliminary Statement on Nigeria's 2015 Elections'. 2015

[16] Mohammed Uwais, 'Report of the Electoral Reform Committee' 2008.

[17] Clifford Ndajhe, "2015: Are the polls really credible, free and fair?” Saturday Vanguard May 2, 2015.

[18] Itse Sagay, 'A Farewell to Election Petitions'. Reactions to Supreme Court's Decision on Rivers State, April 182016.

\section{Endnotes}

\footnotetext{
i Professor 'Lai Olurode was appointed by Nigeria's then President Goodluck Jonathan as a National Commissioner of the Independent National Electoral Commission (INEC) from 2010 to 2015 . He had since returned to the University of Lagos as a Professor of Sociology.

ii Not a few states and local government authorities owe workers for several months. The issue of unpaid salaries dominated workers charter of demand on the occasion of May Day celebration in Nigeria. See also Daily Trust April 302015 - NLC protests non-payment of salaries in states: The Nation, April 30 2015 'Osun APC appeals to workers to be patient' medical doctors are owed six months salaries in Osun, Punch May 2, 2015

The Kogi State government had announced a cut in workers' salaries by 40 percent. Some states in fact owe teachers more than a year of unpaid salaries. The Secretary to the Government of the Federation had to be locked out as workers protest unpaid salaries The Nation, April 302015.

iii See the lamentations of Prof. Itse Sagay, Political Maturity Ethics and Integrity: The Missing factors in Nigeria's Public Life (Lagos: Rebonik Publications, 2012) at p. 15-16 when he said inter alia.

In 2009 a senator earned N240,000,000 in salaries and allowances whilst his House of Representatives counter-part earned N203,760,000. In other words a
} 
senator earned $\$ 1.7 \mathrm{~m}$ and a member of the House of Representatives earned $\$ 1.45 \mathrm{~m}$ per annum. By contrast, an American Senator earned $\$ 174,000$ per annum and a U.K parliamentarian earned about $\$ 64,000$ per annum

What we know is that the Federal Government spends about $72 \%$ of its budget on re-current expenditure, i.e. public servants, leaving only $28 \%$ for capital votes. The outcome is, of course, total lack of development.

$\mathrm{v}$ In spite of what it calls systemic problems, the European Union Election Observation Mission acknowledged the elections as representing strong electoral competition and commitment.

vi This expression was coined by Governor Ayo Fayose of Ekiti State. See also Dare Olatunji's column in The Nation June 24, 2014

vii The emergence of the major opposition party, the All Progressive Congress (APC) was a surprise to the dominant political party, the Peoples' Democratic Party that had produced government administration since 1999. Both within and outside the Commission, the application by the three political parties to merge generated immense interest. There were palpable fears in government circles that should it materialize, then there are tough political battles ahead and for the opposition groups there were apprehensions about the consequences of failure and about the dream that one day Nigeria would breathe fresh air away from conservative politics. The application for merger itself attracted many legal suits apparently to stop the alliance, bodies with similar names and surreptitiously being sponsored by people in government or their stooges applied to the Commission for registration. There were elements within the Commission that were not comfortable with the proposed merger. On July 31 2013, the Commission at its meeting deliberated on the application by the Action Congress of Nigeria (ACN), the All Nigeria Peoples Party (ANPP) and the Congress for Progressive Change (CPC) and it approved of the merger, cancelled the certificates of registration of the political parties and approved a new name-All Progressive Congress (APC) for the merging political parties. See decision extract of the commission dated July 312013.

viii See the manifestos of the PDP and of the APC for elaboration.

ix The printing of the PVC was haphazard, the register that was used to execute the project was not clean enough, there were several cases of omissions and duplications that AEIS was unable to spot. The distribution of the cards was evidently chaotic and many Nigerians had to go through an ordeal to access their PVC. Whereas the PVC was distributed at the polling unit level, continuous voter registration took place at the ward level. The machines in most cases were old and could not function well. The Commission had tinkered with the idea of distributing the cards as they were produced, but we were bothered about allegations by political elites of impartiality in producing cards of one region before the other. This led to tardiness together with the slow pace of production by the contractor. Upon reflections, may be the Commission could have engaged more than just one contractor to do the job. The contractor was unable to meet several deadlines and it became too late to terminate the contract.

The Commission approved the guidelines for the distribution of the PVC of Feb. 20 2014, barely a year to the original date scheduled for election. It was not until Jan. 312015 that the Commission took the decision to distribute PVC that were harvested from the continuous voter registration exercise.

All these factors were responsible for the eventual shift in the day of the first elections from Feb 14 to March 28 though ostensibly the excuse was the war on terrorism in north-east Nigeria. As at that date of postponement, not only were there many cards yet to be distributed and printed, the card readers had yet to undergo real field testing.

$\mathrm{x}$ The Chairman made a presentation to the Council of State on February 5, 2015. Days after the presentation, acrimonies between the government and the opposition persisted - government insisted that the Commission was not ready for elections while the opposition maintained that from the presentation, Jega demonstrated his readiness The Commission's Chairman maintained, however, that more time would help.

xi Members of the Commission met with the National Security Adviser on Jan 212015 but before the Commission could think through the advice and figure out a new date, the National Security Adviser had thrown a bombshell in faraway London that government had advised INEC to postpone elections as the Commission was not ready. Many Nigerians, according to him, were yet to receive their PVC and PVC were yet to be produced for many.

xii The field testing of the SCR was carried out in 12 states of the federation on March 72015 . All the PVC were read by the SCR but the authentication of the finger print was successful in only 59\% of the cases - The Punch March 112015.

xiii Of a total of $68,833,476$ on the voter register, 56,460,980 PVC (representing $82.03 \%$ ) were collected by their owners. This was an improvement over 45,098,876 (or 65.81\%) distributed as at February 3 2015, two days to the Chairman's presentation before the National Council of State.

xiv Those unfamiliar with the Nigerian election environment may regard the process as unduly cumbersome and protracted but it helps to get people "arrested" in polling unit rather than moving round to commit wanton electoral crimes. But some are advocating for a re-think of this procedure so that accreditation and voting can take place simultaneously. As a matter of fact, there is need for a review of the process as electoral crimes on an election day could not be said to be abating even under the current accreditation and voting regime.

$\mathrm{xV}$ The killings in Rivers State and election-related violence including abridgement of election procedure attracted the attention of domestic and international observer groups. The Commission, on two occasions had to send a team of national commissioners but to no avail. In other states as well, acts of desperation were perpetrated as it was like business as usual - people including INEC staff were caught thumb printing (See The Punch April 15 2015). Police arrested many while perpetrating electoral crimes. It was as if the introduction of an election technology was to no avail. Many including observer stakeholders including observer groups demanded the cancellation of Rivers State governorship election. Governor Amaechi of Rivers state had to set up a nine-man commission of inquiry to investigate politically motivated killings in Rivers State - The Punch April, 172015.

xviThe statement partly read as follows:

The Independent National Electoral Commission (INEC) has been monitoring field reports on the accreditation process since the commencement of the poll this morning. Whereas the process has gone on well in several places, in some others, it has encountered some challenges, especially with the use of the card readers. Consequently, accreditation has been slow in many places and has not commenced at all in some others

Even though the Guidelines for the conduct of the 2015 general elections provide that where card readers fail to work and cannot be replaced, elections in such Polling Units will be postponed to the following day, the scale of the challenge we have observed today has necessitated a reconsideration of this provision of the Guidelines. The Commission has, therefore, decided as part of the Guidelines for the Conduct of the 2015 general elections that in Polling Units where card readers have so failed to work, the Presiding Officer shall manually accredit voters by marking the register of voters, being satisfied that the person presenting a Permanent Voter's Card (PVC) is the legitimate holder of the card.

xvii When Ebenezer Babatope, a chieftain of the PDP, was asked for his views on the 2015 general election. He said as follows among other responses; for example, what has the card readers got to do with our elections? Prof Attahiru Jega said it was in line with recent technology. Which technology? "The card readers were apparently used to manipulate the elections. There was underage voting in the North and nothing was done by Jega".

xviii See comments by Amb. James Entwistle the "PVC better than US voter card" The Punch, March 302015.

xix See editorial on "US Ambassador's diplomatic gaffe", The Punch April 52015.

xx Former President Olusegun Obasanjo tore party membership card at a public event in February, 2015 - See Vanguard 17 February, 2015. What contempt to the party under which he was president for two terms. 